\title{
Incidence and Impact of Swiss Needle Cast in Forest Plantations of Douglas-fir in Coastal Oregon
}

\author{
E. M. Hansen, J. K. Stone, B. R. Capitano, P. Rosso, W. Sutton, and L. Winton, Department of Botany and \\ Plant Pathology, Oregon State University, Corvallis 97331; and A. Kanaskie and M. G. McWilliams, Oregon De- \\ partment of Forestry, Salem 97310
}

\begin{abstract}
Hansen, E. M., Stone, J. K., Capitano, B. R., Rosso, P., Sutton, W., Winton, L., Kanaskie, A., and McWilliams, M. G. 2000. Incidence and impact of Swiss needle cast in forest plantations of Douglas-fir in coastal Oregon. Plant Dis. 84:773-778.

An epidemic of Swiss needle cast, caused by the ascomycete Phaeocryptopus gaeumannii, is causing defoliation and growth reductions in Douglas-fir forest plantations along the Oregon Coast. The area of symptomatic plantations has been monitored annually since 1996 by aerial survey; in spring 1999, 119,500 ha were affected. Pathogen and symptom development have also been monitored on nine permanent plots in stands of differing disease severity. Infection levels and symptom severity are greatest in low elevation plantations close to the coast. In areas of severe disease, trees retain only current year needles. Defoliation is proportional to the number of stomata occluded by pseudothecia of the fungus, with needles being shed when about $50 \%$ of stomata are occupied, regardless of needle age. Fungus sporulation and premature needle abscission are greatest on the upper branches of trees. Annual application of fungicides increases needle retention significantly. Tree height and diameter growth and total tree volume are reduced by disease, and tree volume is significantly correlated with needle retention on our plot trees. The epidemic continues to be most severe in Douglas-fir plantations established on sites where Sitka spruce and western hemlock or red alder predominated in earlier times.
\end{abstract}

Additional keywords: conifer foliage disease

Since about 1990, there has been mounting concern about an epidemic of Swiss needle cast in the coastal forests of Oregon and Washington. While much is known about this disease, most of our knowledge comes from Christmas tree plantations or forests in Europe or New Zealand where Douglas-fir is planted as an exotic species $(2,5,9,12,13)$. In the forests of the Pacific Northwest, where both Douglas-fir and the pathogen are native, there has been little concern about the disease. Phaeocryptopus gaeumannii, the causal agent, is widespread wherever Douglas-fir grows, but until recently it was innocuous in North American forest situations $(2,11)$.

Severely diseased plantations, indicated by obvious yellowing, premature needle loss, and abundant fruiting of P. gaeumannii on 1- and 2-year-old needles, are evident from Coquille and Bandon on the southern Oregon Coast to Shelton on Puget Sound, although damage and attention are concentrated in plantations in the vicinity of Tillamook, OR (Fig. 1). Douglas-fir

Corresponding author: E. M. Hansen

E-mail: Hansene@ava.bcc.orst.edu

Accepted for publication 29 March 2000.

Publication no. D-2000-0508-02R

(C) 2000 The American Phytopathological Society plantations 10 to 30 years old are most visibly affected, but the fungus is present on seedlings after their first growing season in the field, and in mature stands as well. Severely diseased plantations are usually located at lower elevations west of the Coast Ranges. They are often, but not exclusively, in areas with summer fog and often on sites where the previous stand was spruce and hemlock, or hardwoods, usually alder.

Although concern about Swiss needle cast near Tillamook dates only from 1990 or later, there were earlier observations of the disease in the vicinity, and it is almost certain that the fungus is native to the area. E. P. Meinicke (unpublished office report, cited in 2) collected the fungus in 1938 near Otis Junction and Hebo near the center of the current area of severe symptoms, but he stated that it was not causing defoliation or yellowing.

There is apparently only one survey that measured actual infection levels and needle retention in coastal forests. Hood (11) systematically collected branches from young, forest-grown Douglas-fir trees in British Columbia and northwestern Washington and examined them for Phaeocryptopus fruiting bodies and needle retention. The fungus was widespread, but incidence varied with rainfall, from greater than $80 \%$ of needles infected in wet coastal and mountain areas to less than $5 \%$ infection in the rain shadow on the east sides of Van- couver Island, the Olympic Peninsula, and the Coast Mountains of British Columbia. There was no comment on defoliation associated with high infection levels, and overall, $>50 \%$ of 6-year-old needles remained on the sampled branches.

Severe defoliation and growth reduction due to Swiss needle cast disease were observed in Douglas-fir plantations in Switzerland as early as 1925 (9) and were subsequently reported from other European countries (2) and more recently from New Zealand and Australia $(1,12)$. In contrast to the situation in Europe and other areas where Douglas-fir was grown as an exotic, Swiss needle cast was not considered a damaging disease in the Pacific Northwest until the late 1970s. As the Christmas tree industry expanded and the harvest shifted from wild trees to plantations of sheared trees, Swiss needle cast emerged as a serious problem (10). The damaging disease in Christmas tree plantations was contrasted at the time with the generally benign occurrence of the fungus in forest plantations (16).

Swiss needle cast was noted in young forest plantations in Washington State starting in 1980 (17). In severely diseased plantations, many trees were chlorotic, with evidence of growth reduction, and retained only 1 or 2 years of needles. There apparently were no systematic surveys at the time, but observers correlated disease severity variously with planting Douglasfir on "hemlock sites," low elevations, high rainfall, and proximity to the ocean (or Puget Sound). During this same period, isolated, severely diseased plantations of young Douglas-fir just south of Tillamook and near Newport and Waldport, OR, were observed by the senior author. Attention to Swiss needle cast in the forest quickly waned, however, and the regular application of fungicides brought the disease under control in Christmas trees. For another decade, Phaeocryptopus was considered a good example of a common but benign forest pathogen that only becomes damaging on off-site trees and in altered environments.

The severity and duration of the current outbreak of Swiss needle cast have raised many questions and generated a research program designed to better understand the causes and consequences of this epidemic. In this paper, we report the distribution of Swiss needle cast in forests in western 
Oregon and its impact on Douglas-fir, including observations associating the abundance of the fungus in needles with defoliation and tree growth reduction.

\section{MATERIALS AND METHODS}

Aerial survey. Beginning in 1996, the Oregon Department of Forestry has annually mapped the distribution of Swiss needle cast in obviously affected Douglas-fir plantations by aerial survey. Flights were made in April or May of each year, at 450 to $600 \mathrm{~m}$ above the terrain, following north-south lines separated by $3.2 \mathrm{~km}$. The survey extended eastward into the Coast Ranges until obvious symptoms were no
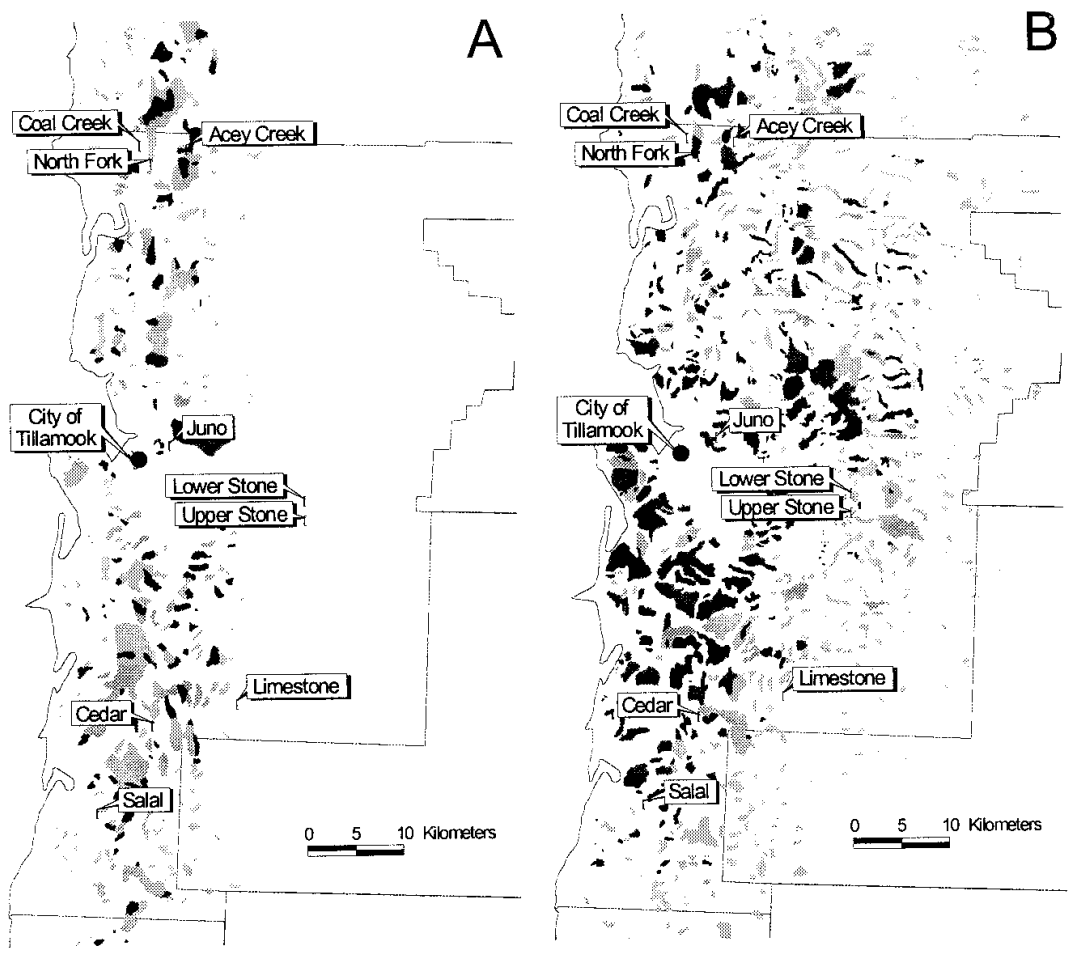

Fig. 1. Increase in incidence and severity of Swiss needle cast in the vicinity of Tillamook, OR, as mapped in the 1996 (A) and 1999 (B) aerial surveys, and locations of study plots. The lightly shaded areas were mapped with "low discoloration," and the darkly shaded areas showed "high discoloration." longer visible, and from the Columbia River (latitude $46^{\circ} \mathrm{N}$ ) to near Bandon, OR (latitude $43^{\circ} \mathrm{N}$ ). Observers looked for areas of Douglas-fir forest with abnormally yellow to yellow-brown foliage. Patches of symptomatic forest (polygons) were drawn onto 1:100,000 scale topographic maps and classified for degree of discoloration as either " $\mathrm{L}$ " or " $\mathrm{H}$ " for light and heavy. Douglas-fir trees in polygons classified as $\mathrm{H}$ had very sparse crowns and brownish foliage, while polygons classified as L had predominantly yellow to yellow-brown foliage and slightly denser crowns.

Disease development. Most measurements of disease impact were made in nine disease monitoring plots established in 1996, arranged in three clusters of three plots each in the vicinity of Tillamook (Table 1, Fig. 1). The plots in each cluster were placed in Douglas-fir plantations of the same age and, where possible, the same seed source. Plantations were selected to represent different elevations and distances from the ocean and exhibited a range of disease severity.

The South Cluster plots are all USDA Forest Service progeny test plantations. Ten trees of each of two families were selected for measurements in each plantation. Plots of the Tillamook Cluster were planted with seedlings from the same bulk seed lot, from the "Boundary" seed collection area of the Coast Ranges, at about 600-m elevation. Ten trees were randomly selected for measurements in each plantation. The North Cluster included one plot planted with the Boundary source (North Fork) and two Oregon Department of Forestry progeny test plantations. Ten trees of each of two families (different from the South plots) were selected for measurements in each of the latter plantations, and 10 trees were measured at North Fork.

Plot measurement trees have been monitored for growth, needle retention, and sporulation of $P$. gaeumannii since 1996. Tree volume was calculated with a formula derived for young-growth trees (3). Except where otherwise noted, needle retention and fungus sporulation were measured in spring, just before budburst, on secondary and tertiary branches of the fifth whorl from the apex of the tree. The density of fruiting bodies (pseudothecia) was measured by counting (or in some cases estimating to the nearest $10 \%$ ) pseudothecia on a sample of 100 contiguous stomata on each of 10 needles chosen randomly from each annual needle complement (internode).

The incidence of infection, as measured by sporulation, was the proportion of needles with pseudothecia anywhere on the stomatal surface. Needle retention was estimated on a 0 to 9 scale, with $0=0$ to

Table 1. Location and other characteristics of Swiss needle cast field plots in Douglas-fir plantations in the vicinity of Tillamook, OR, on the Oregon Coast in 1996

\begin{tabular}{|c|c|c|c|c|c|c|}
\hline Site & Elevation (m) & $\begin{array}{c}\text { Distance } \\
\text { to ocean }(m)\end{array}$ & $\begin{array}{l}\text { Visual disease } \\
\text { severity }^{x}\end{array}$ & Age & Location & Ownership \\
\hline \multicolumn{7}{|l|}{ North Cluster } \\
\hline Acey Crk Progeny & 204 & 8 & Healthy & 10 & T3N, R9W, Sec5 & $\mathrm{ODF}^{\mathrm{y}}$ \\
\hline Coal Crk Progeny & 67 & 5 & Moderate & 10 & T3N, R10W, Sec2 & ODF \\
\hline North Fork & 49 & 4.75 & Severe & 10 & T3N, R10W, Sec2 & ODF \\
\hline \multicolumn{7}{|l|}{ Tillamook Cluster } \\
\hline Upper Stone & 518 & 14.5 & Healthy & 14 & T1S, R8W, Sec35 & ODF \\
\hline Lower Stone & 131 & 14.8 & Mild & 14 & T1S, R8W, Sec35 & ODF \\
\hline Juno Hill & 116 & 2.3 & Severe & 14 & T1S, R9W, Sec17 & ODF \\
\hline \multicolumn{7}{|l|}{ South Cluster } \\
\hline Limestone Progeny & 271 & 12.3 & Healthy & 9 & T4S, R8W, Sec6 & USFS $^{z}$ \\
\hline Cedar Progeny & 457 & 7.5 & Mild & 9 & T4S, R9W, Sec17 & USFS \\
\hline Salal Progeny & 113 & 4 & Moderate & 9 & T5S, R10W, Sec10 & USFS \\
\hline
\end{tabular}

${ }^{\mathrm{x}}$ Sites were rated according to needle retention and discoloration scores.

y Oregon Department of Forestry, Tillamook State Forest.

${ }^{\mathrm{z}}$ USDA Forest Service, Suislaw National Forest. 
$9 \%$ retention and $9=90$ to $100 \%$ retention for each annual complement of needles. Three-year needle retention scores for a tree were obtained by totaling the retention estimates for each needle complement and dividing by 3 . Thus a tree or a branch holding $99 \%$ (score 9) of 1-year-old needles, 90\% (score 9) of 2-year-old needles, and $50 \%$ (score 5) of 3-year-old needles would have a 3 -year needle retention score of 7.8 .

The causal relationship between Phaeocryptopus infection and needle retention was further investigated with fungicide applications. Six 2.5-ha blocks in a 16year-old plantation south of Tillamook that showed symptoms of Swiss needle cast, including chlorosis, needle loss, and reduced growth, were selected for the study. Three blocks were randomly chosen for aerial fungicide application, and three remained as untreated controls. Fungicide was applied by helicopter spray two times a year in 1996 to 1999 . The first treatment was applied when approximately $40 \%$ of the buds had flushed, and the second was applied 2 to 3 weeks later after approximately $90 \%$ of buds had flushed. Bravo 720 (Zeneca, Wilmington, DE) was applied at a rate of 6.43 liters/ha. Needle retention was assessed for 10 trees in each block in April 1999.

A second fungicide experiment was established on 25 trees on Juno Hill, near Tillamook. Pairs of branches from the same whorl on each tree were selected for treatment. One branch of each pair was sprayed once with Bravo 720; the other was left as an untreated control. Sprays were applied by backpack sprayer once each year when approximately $90 \%$ of buds had flushed from 1995 to 1999 . Needle retention was assessed in April 1999 for the previous 4 years' growth.

The Systat 8.0 (SPSS Inc., Chicago, IL) statistics package was used for analysis. Comparisons between plots were made with ANOVA using the Tukey means separation test. Correlations between tree volume and needle retention were tested using Pearson correlation with Dunn-Sidak probabilities. Within tree comparisons used a paired $t$ test.

\section{RESULTS}

Aerial survey. The survey covered about 1,156,000 ha of forest. In the 1999 survey, about 119,500 ha of Douglas-fir forest had obvious symptoms of Swiss needle cast (light and heavy combined), up from 52,600 ha in the 1996 survey (Table 2, Fig. 1). The increase resulted from an increase in frequency of visibly diseased plantations within the original area surveyed, and the extension of the area of visible disease to the east.

Pseudothecial density and needle retention. Pseudothecial density increased with needle age, and increasing proportions of stomata occupied by pseudothecia were associated with increasing amounts of defoliation. Eighteen trees showing a range of foliage retention were selected in April 1996 in eight plantations near Tillamook to examine the relationship between needle retention and density of pseudothecia (Table 3). Severely defoliated trees, retaining only 1-year-old needles, had high pseudothecial density (50\% of stomata occupied) on those needles. Trees retaining 4 years of needles typically had very low levels of fruiting on the 1-year-old needles, with pseudothecial density gradually increasing to an average of $51 \%$ on the oldest complement of needles retained by each tree.

Defoliation of many trees appeared to be greater in the upper crown than in the lower crown. Differences in needle retention and pseudothecial density between upper and lower crown were compared on one tree from each of seven of the study sites (Table 4). In April 1997, a branch from the 1990 or 1992 whorl (7 or 5 years old) was collected from the lower crown, and a branch from the 1994 whorl (3 years old) was collected from the upper crown of each tree. Needle retention was scored for

Table 2. Area (hectares) of Douglas-fir forest in western Oregon with symptoms of Swiss needle cast detected by aerial survey in spring 1996 to 1999

\begin{tabular}{lrccc}
\hline Region & $\mathbf{1 9 9 6}$ & $\mathbf{1 9 9 7}$ & $\mathbf{1 9 9 8}$ & $\mathbf{1 9 9 9}$ \\
\hline North Coast & 42,900 & 46,600 & 54,700 & 105,300 \\
South Coast & 9,700 & 12,100 & 15,400 & 14,200 \\
Total & 52,600 & 58,700 & 70,000 & 119,500 \\
\hline
\end{tabular}

Table 3. Density of Phaeocryptopus gaeumannii pseudothecia, measured as pseudothecia per 100 stomata shortly before budburst, on 1-year-old and older needles for 18 Douglas-fir trees that varied in the average number of years that needles were retained

\begin{tabular}{lcccccc}
\hline & & \multicolumn{2}{c}{$\begin{array}{c}\text { Pseudothecia density } \\
\text { oldest needles }\end{array}$} & & \multicolumn{2}{c}{$\begin{array}{c}\text { Pseudothecia density } \\
\text { 1-year-old needles }\end{array}$} \\
\cline { 6 - 7 } $\begin{array}{l}\text { Needle retention } \\
\text { (years) }\end{array}$ & $\begin{array}{l}\text { Number } \\
\text { of trees }\end{array}$ & Mean & Range & & Mean & Range \\
\hline 4 & 3 & 51 & $40-63$ & & 6 & $1-11$ \\
3 & 6 & 50 & $32-66$ & & 3 & $2-6$ \\
2 & 5 & 62 & $27-90$ & & 36 & $24-58$ \\
1 & 4 & 50 & $35-60$ & & 50 & $35-60$ \\
\hline
\end{tabular}

Table 4. Differences in needle retention and pseudothecial density by needle age and position in the tree for one Douglas-fir tree from near each of seven Swiss needle cast measurement plots near Tillamook on the Oregon Coast ${ }^{2}$

\begin{tabular}{lcccc}
\hline & & 3-year & \multicolumn{2}{c}{ Pseudothecia density } \\
\cline { 5 - 5 } Site & Whorl & retention score & 1-year-old needles & 2-year-old needles \\
\hline Upper Stone & 1994 & 7.3 & 1 & 28 \\
Lower Stone & 1990 & 8.7 & 0 & 20 \\
Juno & 1994 & 5.3 & 11 & 56 \\
& 1990 & 6.7 & 2 & 37 \\
Limestone & 1994 & 3.0 & 50 & 88 \\
\multirow{2}{*}{ Salal } & 1990 & 3.1 & 24 & 30 \\
& 1994 & 5.3 & 5 & 16 \\
Acey & 1992 & 6.3 & 0 & 71 \\
& 1994 & 4.8 & 3 & 69 \\
North Fork & 1990 & 7.0 & 1 & 25 \\
& 1994 & 7.0 & 0 & 16 \\
\hline
\end{tabular}

${ }^{\mathrm{z}}$ The 1994 branch whorl was 3 years old, and the 1990 (or 1992) whorl was 7 (or 5) years old. each branch, and pseudothecial density was
determined for 1- (1997) and 2-year-old (1996) needles. The pseudothecial density decreased on both 1- and 2-year-old neeand needle retention increased $(P \leq 0.002)$ the 1994 whorl (top) to the 1990 or

Fungicide applications reduced pseudothecial density (data not shown) and inspray applications, needle retention for $1-$, $2-$, and 3 -year-old needles was signifi-
cantly increased $(P \leq 0.01)$ compared with the unsprayed controls. Average needle upper crowns of treated trees was $94 \%$ for needles, $80 \%$ for 1997 needles, and (ees. Needle retention was also signifibranch treatments for all 4 years of treatAverage needle retention in 1999 for 1997 , and $16 \%$ for 1996 and 1995 needle complements, compared with 58,7 , and $0 \%$, respectively, on unsprayed branches. 50 , and $17 \%$, respectively, for untreated 
Differences in disease development on permanent plots. Visible differences in fungus development, needle retention, and tree growth were observed between low elevation coastal plots and higher elevation inland plots each year of measurement. The differences were evident in all three plot series, with low elevation plots exhibiting significantly lower needle retention and tree growth and higher pseudothecial density than higher elevation plots (Table 5). Mid-elevation plots usually had intermediate disease values and were often not significantly different from the high elevation plots. Differences in needle retention between tree families were not consistent and not statistically significant $(P=0.84)$ in either the North Cluster of plots or the South Cluster, and data for both families were combined for each plot.

Needle retention differed significantly between plots in each cluster. In May 1998, nearly all trees on all plots retained more than $80 \%$ of 1 -year-old needles, and almost no trees retained 4-year-old or older needles on any of the plots. Significant differences occurred, however, in the retention of 2- and 3-year-old needles and the 3-year retention score as well as in pseudothecial density on older needles (Table 5).

Pseudothecia of $P$. gaeumannii were present in April or May (before budburst) of each year on virtually every 2-year-old or older needle of every tree on each plot. Incidence on 1-year-old needles varied between plots. In the Tillamook cluster of plots, for example, the proportion of 1year-old needles bearing pseudothecia in the spring of 1999 averaged $92.2 \%$ at the high elevation Upper Stone plot and $99.6 \%$ at the low elevation, high disease Juno Hill plot. The rate of development and density of pseudothecia on needles also varied significantly between plots. On currentyear needles, pseudothecia appeared earlier in the season on the low elevation plots than on the higher plots. For example, pseudothecia were visible on 1998 needles at Juno Hill and Salal in October 1998, but did not emerge at Upper Stone and Limestone until February or March 1999.

Pseudothecial density on 1-year-old needles was consistently and significantly greater $(P \leq 0.05)$ at the low elevation plots than at the corresponding higher elevation plots. In 1996, for example, density was $8.6 \%$ at North Fork, $34.7 \%$ at Juno, and $3.5 \%$ at Salal, compared with $2.0 \%$ at Acey, $0.8 \%$ at Upper Stone, and $1.2 \%$ at Limestone, respectively. In 1998, when densities were estimated, not counted, only Juno Hill had a significantly greater density of pseudothecia on current-year needles. Significant differences were detected on 2-year-old foliage (Table 5).

Differences in tree growth were evident between low elevation plots (with greater pseudothecial density and lower needle retention) and the higher elevation plots in each cluster (Table 5). The Tillamook Cluster exhibited the greatest range. Tree height, diameter, and cubic stem volume at Juno were 55,43 , and $11 \%$ of the corresponding measures on trees of the same age and same seed source planted at Upper Stone. Correlations between needle retention and tree volume were significant $(P \leq$ $0.0005)$ for the Tillamook Cluster $\left(r^{2}=\right.$ $0.51)$ and the South Cluster $\left(r^{2}=0.25\right.$, data not shown). Correlation between retention score and tree volume for the North Cluster was low $(P \leq 0.25)$.

\section{DISCUSSION}

Symptoms of chlorosis, decreased needle retention, and growth reduction observed on Douglas-fir in the Tillamook area are consistent with symptoms of Swiss needle cast reported from forests in Europe and New Zealand, and the 1980s reports from Washington. There has been an impression that defoliation is not well correlated with infection by the fungus. Certainly most if not all Douglas-fir trees in the Coast Ranges are infected with the fungus, as evidenced by pseudothecia, but trees differ widely in needle retention. The present work demonstrates, however, that there is a good correlation between the density of fungus fruiting on 1- and 2-yearold needles (not simply presence or absence of the fungus) and needle retention on the same trees (Table 3).

Consistently greater needle retention in foliage sprayed with chlorothalonil indicates the involvement of a fungal foliar pathogen in the defoliation of Douglas-fir trees on the Oregon coast. $P$. gaeumannii is the only foliar pathogen observed on the trees before treatment and is the only pathogen that is abundant throughout the area of the epidemic. Several Rhabdocline species also invade Douglas-fir needles soon after budbreak and have a 1-year development (7), but they are only occasionally encountered in the area, and never in our study plots. In particular, Rhabdocline has historically been a problem on old off-site plantations in the Hebo area south of Tillamook, but it is seldom seen in recent plantations. Fungicides are routinely used to increase needle retention in Christmas trees affected by Swiss needle cast (5).

Most infection occurs in newly emerged current-season needles, and the first fruiting bodies appear late in the first year (13), but the number of fruiting bodies visible on needles increases with needle age. The fungus increases vegetatively from year to year, both within the needle and as hyphae on the needle surface, until the needle is dropped (4). In this work, we observed that needles were generally shed when more than $50 \%$ of the stomata were visibly occupied by pseudothecia of the fungus. In February, the oldest needles on a branch had about $50 \%$ of stomata with pseudothe-

Table 5. Phaeocryptopus gaeumannii pseudothecial density, needle retention, tree height and diameter, and cubic stem volume for Douglas-fir trees at nine Swiss needle cast plots differing in needle cast severity, from measurements in April 1998

\begin{tabular}{|c|c|c|c|c|c|c|c|c|c|}
\hline \multirow[b]{2}{*}{ Site/family } & \multicolumn{2}{|c|}{ Pseudothecia $^{x}$} & \multicolumn{3}{|c|}{ Needle retention ${ }^{y}$} & \multirow{2}{*}{$\begin{array}{l}\text { 3-year } \\
\text { score }\end{array}$} & \multirow{2}{*}{$\begin{array}{l}\text { Diameter } \\
\text { (cm) }\end{array}$} & \multirow{2}{*}{$\begin{array}{c}\text { Height } \\
\text { (m) }\end{array}$} & \multirow{2}{*}{$\begin{array}{c}\text { Volume } \\
\left(\mathbf{m}^{3}\right)\end{array}$} \\
\hline & 1997 & 1996 & 1997 & 1996 & 1995 & & & & \\
\hline \multicolumn{10}{|l|}{ North Cluster } \\
\hline Acey Crk Progeny & $2.0 \mathrm{a}$ & $2.1 \mathrm{a}$ & $9.0 \mathrm{a}^{\mathrm{z}}$ & $8.7 \mathrm{a}$ & $3.7 \mathrm{a}$ & $7.1 \mathrm{a}$ & $14.5 \mathrm{a}$ & $9.9 \mathrm{a}$ & $0.07 \mathrm{a}$ \\
\hline Coal Crk Progeny & $2.1 \mathrm{a}$ & $2.6 \mathrm{ab}$ & $8.1 \mathrm{a}$ & $6.9 \mathrm{~b}$ & $1.6 \mathrm{~b}$ & $5.2 \mathrm{~b}$ & $13.6 \mathrm{ab}$ & $8.9 \mathrm{~b}$ & $0.06 \mathrm{a}$ \\
\hline North Fork & $2.5 \mathrm{a}$ & $3.0 \mathrm{~b}$ & $8.5 \mathrm{a}$ & $6.3 \mathrm{~b}$ & $1.8 \mathrm{ab}$ & $5.5 \mathrm{~b}$ & $11.4 \mathrm{~b}$ & $6.9 \mathrm{c}$ & $0.03 \mathrm{~b}$ \\
\hline \multicolumn{10}{|l|}{ South Cluster } \\
\hline Limestone Progeny & $1.9 \mathrm{a}$ & $2.3 \mathrm{a}$ & $8.9 \mathrm{a}$ & $8.2 \mathrm{a}$ & $5.9 \mathrm{a}$ & $7.7 \mathrm{a}$ & $12.2 \mathrm{a}$ & $8.2 \mathrm{a}$ & $0.04 \mathrm{a}$ \\
\hline Cedar Progeny & $2.2 \mathrm{a}$ & $2.3 \mathrm{a}$ & $9.0 \mathrm{a}$ & $7.7 \mathrm{a}$ & $5.4 \mathrm{a}$ & $7.4 \mathrm{a}$ & $11.2 \mathrm{ab}$ & $7.3 \mathrm{a}$ & $0.03 \mathrm{ab}$ \\
\hline Salal Progeny & $2.5 \mathrm{a}$ & $2.7 \mathrm{ab}$ & $8.8 \mathrm{a}$ & $6.8 \mathrm{a}$ & $1.7 \mathrm{~b}$ & $5.8 \mathrm{~b}$ & $9.2 \mathrm{~b}$ & $5.8 \mathrm{~b}$ & $0.02 \mathrm{~b}$ \\
\hline \multicolumn{10}{|l|}{ Tillamook Cluster } \\
\hline Upper Stone & $2.6 \mathrm{a}$ & $3.0 \mathrm{~b}$ & $9.0 \mathrm{a}$ & $8.9 \mathrm{a}$ & $6.1 \mathrm{a}$ & $8.0 \mathrm{a}$ & $17.8 \mathrm{a}$ & $10.6 \mathrm{a}$ & $0.12 \mathrm{a}$ \\
\hline Lower Stone & $2.1 \mathrm{a}$ & $3.2 \mathrm{~b}$ & $8.9 \mathrm{a}$ & $8.0 \mathrm{a}$ & $4.4 \mathrm{a}$ & $7.1 \mathrm{a}$ & $16.7 \mathrm{a}$ & $11.4 \mathrm{a}$ & $0.12 \mathrm{a}$ \\
\hline Juno Hill & $4.3 \mathrm{~b}$ & $4.4 \mathrm{c}$ & $8.8 \mathrm{a}$ & $4.4 \mathrm{~b}$ & $0.0 \mathrm{~b}$ & $4.4 \mathrm{~b}$ & $7.6 \mathrm{~b}$ & $5.8 \mathrm{~b}$ & $0.01 \mathrm{~b}$ \\
\hline
\end{tabular}

x Pseudothecial density estimated for samples of 10 needles from each age complement for 10 or 20 trees per site. $1=0$ to $10 \%, 2=10$ to $20 \%, 3=20$ to $30 \%, 4=30$ to $40 \%, 5=40$ to 50\%. Data were analyzed by Kruskal-Wallis and Kolmogorov-Smirnov two sample tests. Within columns, numbers followed by the same letter are not significantly different $(P=0.95)$.

${ }^{\mathrm{y}}$ Needle retention scored 0 to 9 for each annual needle complement, with $0=0$ to $9 \%$ retention and $9=90$ to $100 \%$ retention. 3 -year score is the average retention for those 3 years.

${ }^{\mathrm{z}}$ Within a cluster of plots, numbers in the same column followed by the same letter are not significantly different $(P \leq 0.05)$. 
cia, regardless of how many cohorts of needles were retained. Thus, trees holding only current year's needles had $50 \%$ of the stomata occluded on those needles, and trees holding 3 years of needles had $50 \%$ of the stomata occluded on the 3-year-old needles, but much less sporulation on 1and 2-year-old needles (Table 3).

It has been noted in New Zealand (14) and on the Oregon coast (Table 4) that defoliation is most severe in the upper portion of the tree crown. This contrasts with a normal pattern of lower crown defoliation associated with other foliage diseases and also with the pattern of Swiss needle cast symptoms in Christmas trees $(6,15)$. Recent work on disease physiology (D. Manter, P. Rosso, and K. Kavanagh, unpublished) suggests that occlusion of the stomata during sporulation physically interferes with stomatal function, gas exchange, and regulation of water loss. The consequence to the tree is premature loss of heavily colonized needles. On sites where disease is severe, such as Juno Hill, trees hold only current-year needles and have reduced growth. Ultrastructural observations of infected needles (4) show extensive growth of $P$. gaeumannii hyphae in intercellular spaces, often adhering to cell walls, but no evidence of cell penetration or disruption. It appears that the fungus obtains nutrients from the intercellular spaces, perhaps by altering membrane permeability.

Swiss needle cast infection and subsequent needle loss may ultimately result in diminished height and diameter growth by the tree, although there have been no direct measurements of actual growth reductions due to lack of uninfected controls in the affected forest plantations. In our study, correlations between needle retention and growth are weak, probably because of small sample sizes and the uncontrolled effects of differences in site quality and competing vegetation on growth. Other work (D. Maguire, 1998 Annual Report to the Swiss Needle Cast Cooperative, Oregon State University), based on many more plots and controlling for competitive interactions and expected site productivity, estimates average growth reduction in 10to 30-year-old Douglas-fir plantations along the North Oregon coast during the current epidemic at 23\%. Estimates from New Zealand indicate that 80-year-old trees holding only 2 years of needles were producing about $50 \%$ of the projected annual volume increment (1).

Concern about Swiss needle cast continues to grow in the western Douglas-fir region, and the annual aerial survey confirms that the area of forest visibly affected is increasing. The affected area is still concentrated close to the coast, but now extends further east and further south in the Coast Range. Anecdotal reports suggest that disease severity is increasing along the Washington coast as well, and there are isolated reports of symptomatic plantations in the foothills of the Cascade Mountains. We have also noted that symptom development is influenced by weather patterns in late winter and early spring. Warm dry weather enhances symptoms and could affect aerial survey results.

Accurately predicting the course of this epidemic of a native pathogen on its natural host requires an understanding of its origins. Many hypotheses have been put forward, ranging from a novel, more virulent race of the pathogen to site deterioration from intensive forestry. One hypothesis that has been raised repeatedly suggests that changes in forest management and climatic factors coincided to trigger the epidemic: a combination of increasing abundance of Douglas-fir in coastal stands and a climatic cycle providing favorable conditions for infection and disease development.

Because of strong economic incentives in recent decades, many landowners have converted cut-over coastal lands that had regenerated naturally to alder and mixed conifers, predominantly Sitka spruce and western hemlock, to Douglas-fir plantations. Although historical records are scant, many of these Douglas-fir plantations are growing on sites previously occupied by hardwoods, spruce, and hemlock. In 1997, the Oregon Department of Forestry (unpublished data) investigated the history of 76,970 ha of Douglas-fir plantations 10 to 30 years old growing within $29 \mathrm{~km}$ of the north Oregon Coast. About $31 \%$ of these plantations had been established on sites where hemlock and spruce had dominated the previous stand. Only $20 \%$ were on sites dominated by Douglas-fir in the previous rotation. The remaining areas were mostly alder stands that had been converted to Douglas-fir. Their earlier history is unknown.

Much of the land that has been converted to Douglas-fir plantations in recent decades, and where most severely affected plantations are located, lies in the Picea sitchensis vegetation zone, a narrow strip of coastal forest characterized by elevations generally below $150 \mathrm{~m}$, proximity to the ocean, and a moderate climate (8). It does not have a sharp boundary to the east, but grades into the Tsuga heterophylla zone, where Douglas-fir is the natural seral dominant, that comprises most of the forest area west of the crest of the Cascade Mountains. In contrast, Douglas-fir is a relatively minor component of the natural vegetation in the $P$. sitchensis zone, where it normally occurs in mixtures of spruce and hemlock, not as pure stands (8). Thus, on many lowland coastal sites where Douglas-fir historically has been an infrequent component of the vegetation, it has recently become a more dominant species.

Subtle climatic differences that are primarily responsible for the different vegetation composition of the $P$. sitchensis and $T$. heterophylla zones also are likely important factors in disease severity. Areas with severe Swiss needle cast are found at lower elevations, near the ocean. In most cases, including our plot clusters, it is possible to travel a few miles inland and a few hundred meters higher in elevation and find plantations of the same age and seed source with few symptoms of disease, where needle retention is 3 or 4 years on average. The fungus is still abundant, but only on the older needles. Environmental differences between such nearby sites are subtle, but perhaps significant. Temperatures are milder, and annual rainfall is actually lower closer to the coast in the Picea sitchensis zone than it is at higher elevations in the Coast Range. In late spring and early summer, however, during the infection period for the fungus, total precipitation is similar, but wet conditions persist longer in the $P$. sitchensis zone due to the greater incidence of fog and low clouds close to the ocean and bays. Summer high temperatures are lower and winter temperatures are warmer in the spruce zone (8).

Although $P$. gaeumannii is endemic to coastal Oregon, an increase in the proportion of Douglas-fir in recent decades, its concentration in pure stands, and favorable climatic conditions may have enabled $P$. gaeumannii to increase above historically normal levels in coastal forests, leading to increased disease pressure. Under this increased inoculum pressure, even a naturally tolerant host population may be adversely affected.

Genetic composition of the Douglas-fir plantations may also be important. In Douglas-fir progeny tests in British Columbia (11), seedling families originating from drier areas east of the Coast Ranges were more susceptible to Swiss needle cast than families collected from wet forests near the coast. In many cases in the Tillamook area, seed used in low elevation coastal plantations originated from higher elevations in the Coast Ranges. It might be expected that trees that evolved in warm and dry climates less favorable to the fungus would have less genetic resistance than trees evolved in nearby areas where genetic resistance was perhaps essential to survival.

It is too early to predict the outcome of this epidemic on Douglas-fir plantations in the Oregon Coast Ranges. Research is continuing to examine potential benefits of thinning and fertilizing stands of different ages and disease severity, tree genetics, and the biology of the pathogen. Meanwhile, some landowners in the area most severely impacted (corresponding to our low elevation-high disease plots) are converting their Douglas-fir plantations to spruce and hemlock, as circumstances allow.

\section{ACKNOWLEDGMENTS}

We thank the Oregon Department of Forestry and the Swiss Needle Cast Research Cooperative for financial support of this research. The SNC 
Coop is comprised of industrial, federal, and state forest landowners in Oregon and Washington.

\section{LITERATURE CITED}

1. Beekhuis, J. 1978. Growth decline in Douglas-fir. Pages 119-125 in: A Review of Douglas-fir in New Zealand. R. N. James and E. H. Bunn, eds. Forest Research Institute, Rotorua, New Zealand. FRI Sympos. 15.

2. Boyce, J. S. 1940. A needle-cast of Douglas Fir associated with Adelopus gaeumannii. Phytopathology 30:649-659.

3. Bruce, D., and DeMars, D. J. 1974. Volume Equations for Second-growth Douglas-fir. U.S. Dep. Agric. For. Serv. Res. Note PNW239.

4. Capitano, B. R. 1999. The Infection and Colonization of Douglas-fir by Phaeocryptopus gaeumannii. M.S. thesis. Oregon State University, Corvallis.

5. Chastagner, G. A 1997. Christmas tree plantations. Pages 88-89 in: Compendium of Conifer Diseases. E. M. Hansen and K. J. Lewis, eds. American Phytopathological Society, St. Paul, MN.
6. Chastagner, G. A, and Byther, R. S. 1983. Infection period of Phaeocryptopus gaeumannii on Douglas-fir needles in western Washington. Plant Dis. 67:811-813.

7. Chastagner, G. A, Byther, R. S., and Riley, K L. 1999. Maturation and control of Rhabdocline needlecast on Douglas-fir in western Washington. Recent Research on Foliage Diseases. W. Merrill and M. Ostry, eds. U.S. Dep. Agric. For. Serv. Gen. Tech. Rep. WO-56.

8. Franklin, J. F., and Dyrness, C. T. 1973. Natural Vegetation of Oregon and Washington. U.S. Dep. Agric. For. Serv. Gen. Tech. Rep. PNW-8.

9. Gaeumann, E. 1930. Über eine neue Krankheit der Dougalsien. Schweiz. Z. Forstwes. 81:63-67.

10. Hadfield, J., and Douglas, B. 1982. Protection of Douglas-fir Christmas trees from Swiss needle cast in Oregon. Am. Christmas Tree J. 26:31-33.

11. Hood, I. A. 1982. Phaeocryptopus gaeumannii on Pseudotsuga menziesii in southern British Columbia. N.Z. J. For. Sci. 12:415424.
12. Hood, I. A. 1997. Swiss needle cast. Pages 55-56 in: E. M. Hansen and K. J. Lewis, eds. Compendium of Conifer Diseases. American Phytopathological Society, St. Paul, MN.

13. Hood, I. A., and Kershaw, D. J. 1975. Distribution and infection period of Phaeocryptopus gaeumannii in New Zealand. N.Z. J. For. Sci. 5:201-208

14. Hood, I. A., and Wilcox, M. D. 1971. Variation in susceptibility to chlorosis and needle cast associated with Phaeocryptopus gaeumannii infection in an 11-year-old Douglas-fir provenance trial. N.Z. For. Res. Inst. For. Pathol. Rep. 72.

15. Merrill, W., and Longenecker, J. 1973. Swiss needle cast on Douglas-fir in Pennsylvania. Plant Dis. Rep. 57:984.

16. Michaels, E., and Chastagner, G. A 1984 Distribution, severity, and impact of Swiss needle cast in Douglas-fir Christmas trees in western Washington and Oregon. Plant Dis. 68:939-942.

17. Russell, K. 1981. Swiss needle cast in Douglas-fir. Wash. Dep. Natural Resources, For. Land Manage. Rep. 279. 